\title{
Public knowledge, attitudes and perception of ecological debt
}

\author{
Efi Drimili \\ Efthimios Zervas ${ }^{1}$ \\ Hellenic Open University, Greece
}

\begin{abstract}
The concept of ecological debt describes the ecological relations between industrialized (developed) and developing countries and the environment. It refers to the responsibility held by those who live in industrialized countries, as well as their accomplices in the South, for the continuing destruction of the planet due to production and consumption patterns. Ecological debt is a potentially powerful tool for re-discussing relations between North and South and for rethinking sustainable development policies. The aim of the current study is to evaluate the public's knowledge, attitude towards, and perceptions of topics related to the concept of ecological debt. A survey was conducted using a structured questionnaire among residents of Athens, the capital of Greece. To the best of our knowledge this is the first time that this issue has been explored, with regard to public opinion and this is the beginning of a discussion on public understanding of ecological debt. The survey reveals that the concept of ecological debt is not widely understood; but the participants seem to agree on the causes of its generation and on its association with external financial debt. The research findings guide alternative proposals to relevant social movements and/or organizations for the design of wake-up policies.

Keywords: ecological debt, sustainable development, public acceptance, financial debt
\end{abstract}

\section{Résumé}

Le concept de dette écologique décrit les relations écologiques entre les pays industrialisés (développés) et en développement et l'environnement naturel. Il fait référence à la responsabilité de ceux qui vivent dans les pays industrialisés, ainsi que de leurs complices du Sud, pour la poursuite de la destruction de la planète due aux modes de production et de consommation. La dette écologique est un outil potentiellement puissant pour repenser les relations entre le Nord et le Sud et pour repenser les politiques de développement durable. L'objectif de la présente étude est d'évaluer les connaissances, l'attitude et les perceptions du public à l'égard de sujets liés au concept de dette écologique. Une enquête a été menée à l'aide d'un questionnaire structuré auprès des résidents d'Athènes, la capitale de la Grèce. À notre connaissance, c'est la première fois que cette question a été explorée, en ce qui concerne l'opinion publique. Ceci est le début d'une discussion sur la compréhension publique de la dette écologique. L'enquête révèle que le concept de dette écologique n'est pas bien compris. mais les participants semblent s'accorder sur les causes de sa génération et sur son association avec la dette financière extérieure. Les résultats de cette recherche peuvent fournir aux mouvements sociaux et/ou organisations des propositions alternatives pour la construction de programmes de sensibilisation sociale.

Mots-clés: dette écologique, développement durable, acceptation publique, dette financière

\section{Пері́ $\eta \psi \eta$}

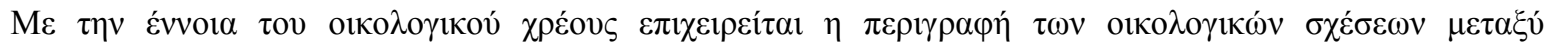

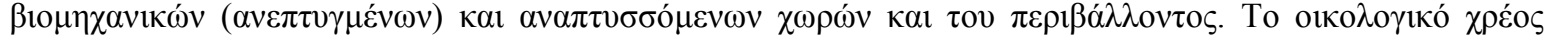

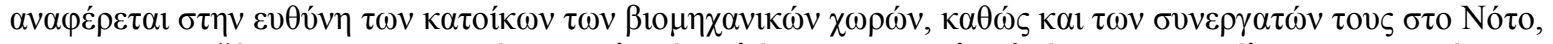

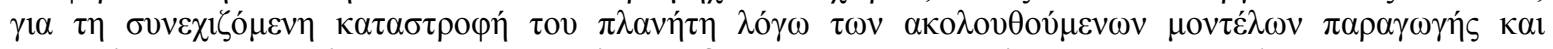

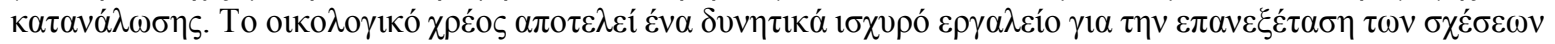

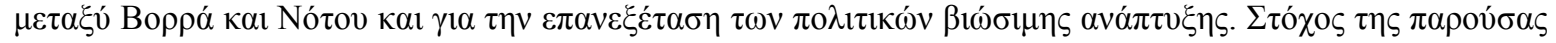

\footnotetext{
${ }^{1}$ Efi Drimili, PhD student and Dr. Efthimios Zervas, Professor, Laboratory of Technology and Policy of Energy and Environment, School of Science and Technology, Hellenic Open University, Parodos Aristotelous 18, 26335 Patra, Greece. Emails: efidrim "at" yahoo.gr and zervas "at" eap.gr. We are grateful to all those people who participated in the survey and shared their valuable knowledge with us. We would like to thank Professor Simon Batterbury and the anonymous JPE reviewer for their useful comments that helped to improve the manuscript for publication.
} 


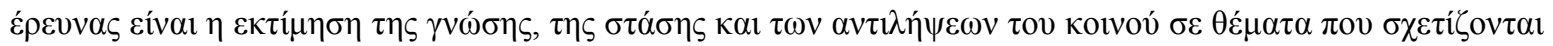

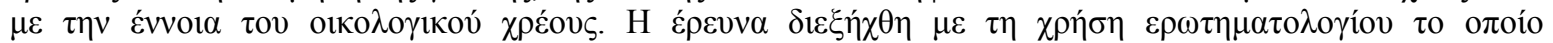

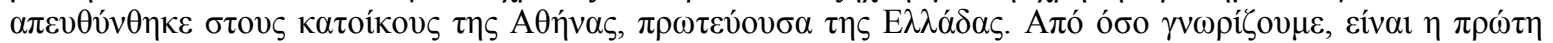

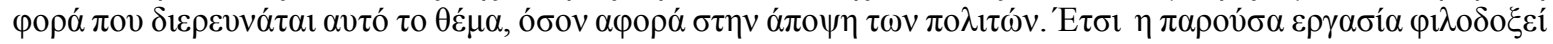

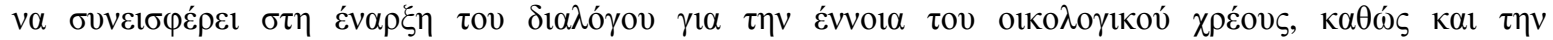

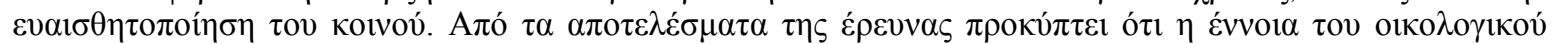

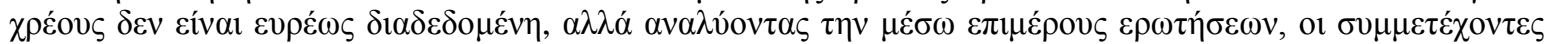

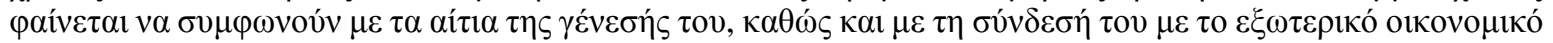

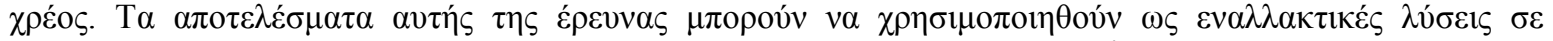

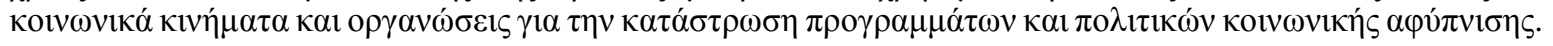

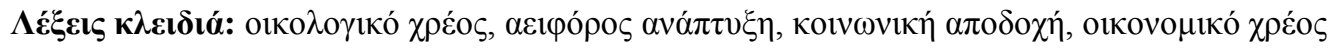

\section{Introduction}

Ecological debt is a concept of political ecology that has its origins outside academia (Martínez Alier et al. 2014). The concept received attention in an international context at the beginning of the 1990s as an Alternative Treaty for a more sustainable world, at the Global Forum during the 1992 United Nations Conference on Environment and Development (UNCED) in Rio de Janeiro. In the years directly following the 1992 Earth Summit, the idea of ecological debt was not taken up. A few scientific articles elaborating the concept of ecological debt appeared during the 1990s (Geominne and Paredis 2008). It was used as a campaign slogan by non-governmental organizations (NGOs), most prominently by the Ecuadorian NGO Acción Ecológica, in the context of campaigns against external financial debt. Acción Ecológica campaigned with the slogan "No more plunder: they owe us the ecological debt" (Acción Ecológica 2000).

The concept of ecological debt attempts to describe the ecological relations between industrialized (developed) and developing countries and the environment. It refers to the responsibility held by those who live in industrialized countries, as well as their accomplices in the South, for the continuing destruction of the planet due to production and consumption patterns. The first definition of the concept of ecological debt was included in the Debt Treaty of 1992. The Debt Treaty pointed out:

...the existence of a planetary ecological debt of the North; this is essentially constituted by economic and trade relations based on the indiscriminate exploitation of resources, and its ecological impacts, including global environmental deterioration, most of which is the responsibility of the North.... (Debt Treaty 1992)

Another definition was proposed some years later by Bravo and Yanez (2003). According to these authors, the ecological debt is defined as:

...the accumulated, historical and current debt which industrialized Northern countries, their institutions and corporations owe to the peoples and countries of the South for having plundered and used their natural resources, exploited and impoverished their peoples, and systematically destroyed, devastated and contaminated their natural heritage and sources of sustenance. (Donoso 2003: 13)

This points out that the consumption and production patterns of the industrialized countries cause debt, and the victim is the planet itself. The mechanism by which the debt is created is defined, namely the looting and use of natural resources (Geominne and Paredis 2010). A more precise definition is proposed by Paredis et al. (2008: 149):

The ecological debt of country A consists of: (a) the ecological damage caused over time by country A in other countries or in an area under jurisdiction of another country through its production and consumption patterns, and/or (b) the ecological damage caused over time by 
country A to ecosystems beyond national jurisdiction through its consumption and production patterns, and/or (c) the exploitation or use of ecosystems and ecosystem goods and services over time by country A at the expense of the equitable rights to these ecosystems and ecosystem goods and services of other countries or individuals.

The significance of this definition is in the choice of the terms it uses, and in the new dimension it gives to the implementation of the ecological debt concept. It uses the term ecological damage instead of environmental damage, advancing from previous definitions to include damage and values that are unpriced. It defines ecological damage spatially and temporally and is formulated in such a way that it can, with the appropriate definition, apply not only to countries but also to other entities (businesses, generations, etc.), who potentially can play the role of creditor and debtor (Geominne and Paredis 2008; Paredis et al. 2008; Warlenius 2016).

The concept of ecological debt covers a broad range of injustices between the global North and South, often starting from ecological themes, but spreading to cover social, cultural and economic impacts (Geominne and Paredis 2008; Warlenius 2016). It could be a potentially powerful tool for the reframing and reorienting of national and international sustainable development policies (Paredis et al. 2008) and might further the struggle for environmental and social justice in the world (Manzano et al. 2016; Rice 2009). Specifically, the concept of ecological debt:

- has the power to acknowledge the interconnections between society, nature and economy that are so often held as separate, irreducible objects within social science and policy making (Rice 2009);

- can acknowledge the inequalities and injustices of the current world order and supporting efforts to use international law to alleviate structural asymmetries in the world economy (Manzano et al. 2016);

- can unite the comparable experiences from (local) groups all over the South and unite them under a new label, 'ecological debt' (Paredis et al. 2008);

- can bring a historical dimension to the sustainability debate, since sustainable development (defined as the "development that meets the needs of the present without compromising the ability of future generations to meet their own need" (Brundtland 1987)) lacks a historical perspective (Paredis et al. 2008);

- and could open a new perspective on debtor-creditor relations in contemporary international politics as a consequence of the link made in the campaigns between external financial debt and ecological debt, reframing the cancellation of external debt as a moral obligation (Paredis et al. 2008).

Ecological debt is considered as a multifaceted concept that requires further elucidation and elaboration (Warlenius et al. 2015). The maturation and stabilization of ecological debt as a powerful constructive tool needs conceptual enrichment. There are three main ways of conceptualizing ecological debt: underpayment debts, biophysical debts, and punitive debts. The first is measured in money, the second in physical units and the third escapes quantitative measurement (Warlenius 2016).

Several researchers have focused more on the mechanisms underlying the concept of ecological debt (such as unequal ecological exchange) and less on the methodology of calculation (Martinez Alier 2002; Warlenius 2016). Martinez-Alier (2002) sees ecological debt as economic concept arising from two separate ecological distribution conflicts. The first is ecologically unequal exchange (the fact that exports of raw materials and other products from relatively poor countries are sold at prices that do not include compensation for local or global externalities). The second is the fact that rich countries make disproportionate use of environmental space or services without payment, and even without recognition of other peoples' entitlements to such services. In the same way, Warlenius (2016) states that ecological debt and ecologically unequal exchange can be linked together analytically as the first denotes a "flow" and the second a "stock." 
Others are focused on quantification (Azar and Holmberg 1995; Jenkins 1996; Smith 1996; Srinivasan et al. 2008; Torras 2003). Azar and Holmberg quantified the ecological debt generated by Belgium; Mariano Torras (2003) linked it to external debt relief, and Mayer and Haas (2016) suggest cumulative material flows as indicators to quantify ecological debt. A quantification methodology should be able to measure different components: first, the ecological damage caused in other countries or an area under jurisdiction of another country and secondly, the use of ecosystems and ecosystem services at the expense of other countries or individuals (even without damage being caused) (Geominne and Paredis 2010). Western obsession with scientific proof can reduce complex human realities to numbers, ruining the chance for these realities to 'speak' (Paredis et al. 2008).

Debates over definition, meaning, and quantification continue. However, to the best of our knowledge, there is little on social opinion of, knowledge of, and acceptance of the concept of ecological debt. This article is a first contribution. It investigates public acceptance and knowledge of the concept among residents of Athens, to raise public awareness and inform social movements and organizations. Ecological debt is an important issue for Greece, which is going through a period of economic crisis and deep economic recession with an unbearable external financial debt.

\section{Materials and methods}

\section{Questionnaire and collection method}

The survey was conducted in Athens from February to April 2017, using a structured questionnaire. A pilot was first administered (Fink 2006; Nardi 2006). Thirty residents of Athens were chosen randomly to comment on the draft questionnaire's clarity and ease of use. Their suggested changes were incorporated into the final questionnaire, consisting of closed-ended questions shown in Table 3 of the Appendix. All items were measured using a five point Likert scale, ranging from 1 (Not at all) to 5 (Absolutely). The questionnaire was divided into three sections.

The first was focused on environmental attitudes and perceptions, and includes questions exploring consciousness of environmental issues, beginning with general environmental interest, the impact of environmental problems on daily lives of citizens, and on the lives of future generations. Next the source of information on environmental issues was defined, since it directly affects the citizens' views. Then how willing are respondents to participate in the protection of the environment? Lastly their views on the role of the state in the implementation of environmental policy and on the feasibility of combining economic growth with environmental protection.

The second section queries knowledge of ecological debt; awareness, aspects of the issue, and views on environmental policies of developed/developing countries. The participants were also asked to assess why richer (industrialized) countries choose to carry out economic activities in poorer (developing) countries. Then, they were asked to express their opinion on the relationship between environmental exploitation and financial debt, and the adoption of more flexible environmental and working legislative frameworks in Greece to attract investments and reduce external financial debt. Finally, they were asked if Greece has an ecological debt, and how the country's external financial debt could be repaid.

The last section of the questionnaire collected basic socio-demographic information (gender, age, marital status, educational level, family income and occupation).

\section{Construction of the sample of the people to interview}

The survey took place in the urban Athens. In total, 568 questionnaires were collected from ten locations, at different times of the day and on different days of the week. The respondents were randomly selected and were aged 18 and older. Some 68 questionnaires were deemed invalid, leaving 500 for analysis. The sample mirrors the gender and age distribution of the permanent population of the Attica Region (Table 1), as recorded in the last national census of 2011 (Hellenic Statistical Authority 2017). 


\begin{tabular}{|c|c|c|c|c|c|c|}
\hline \multirow[t]{2}{*}{ Age } & \multicolumn{4}{|c|}{ Sample $(n=500)$} & \multicolumn{2}{|c|}{$\begin{array}{l}\text { Population }(\mathrm{N}= \\
2,783,545)\end{array}$} \\
\hline & $\begin{array}{l}\text { Female } \\
(\%)\end{array}$ & $\begin{array}{l}\text { Male } \\
(\%)\end{array}$ & $\begin{array}{l}\text { Number (Male } \\
\text { and Female) }\end{array}$ & $\begin{array}{l}\% \text { of the } \\
\text { sample }\end{array}$ & $\begin{array}{l}\text { Female } \\
(\%)\end{array}$ & Male (\%) \\
\hline $18-24$ & 52.5 & 47.5 & 47 & 9.4 & 48.6 & 51.4 \\
\hline $25-44$ & 51.8 & 48.2 & 229 & 45.8 & 50 & 50 \\
\hline $45-54$ & 52 & 48 & 100 & 20 & 53 & 47 \\
\hline $55-64$ & 52.5 & 47.5 & 67 & 13.4 & 53.3 & 46.7 \\
\hline $65-74$ & 51.7 & 48.3 & 57 & 11.4 & 54.7 & 45.3 \\
\hline
\end{tabular}

Table 1: Comparison between the structure of the sample and the population of Athens.

Sampling error is estimated as follows. Statistical theory suggests that the connection between the sample size and the desired margin of error, in case of finite population, is given by the formula (Kothari 1990):

$$
n=\frac{z^{2} * p *(1-p) * N}{M E^{2} *(N-1)+z^{2} * P *(1-p)}
$$

where

- $\mathrm{ME}$ is the desired margin of error,

- $\mathrm{n}$ is the sample size ( $\mathrm{n}=500$ in our case),

- $\mathrm{N}$ is the population size ( $\mathrm{N}=2.783 .545$ adult population of Athens (18-74 years old))

- $\mathrm{p}$ is the preliminary estimate of the proportion in the population (as the value of p was not known the maximum value of 0.50 was assumed)

- $\mathrm{z}$ is the two-tailed value of the standardized normal deviate associated with desired level of confidence (for 95\% confidence interval the value of $z$ was equal to 1.96).

From the above equation, $\mathrm{ME}=0.04$, or $4 \%$, which is less than $5 \%$ (for desired reliability, the acceptable maximum error is 0.05 , with an associated $95 \%$ confidence interval).

\section{Data analysis}

The environmental consciousness of the respondents and their knowledge of the concept of ecological debt were evaluated statistically. Quantitative variables were indicated as mean \pm standard deviation. We calculated frequency analysis, percentages, cross tabulation and chi-squared tests of independence for categorical variables. The frequencies of observed and expected values were analyzed by means of crosstabulations. These revealed the relationships between cross-tabulated variables. The chi-square test for independence was used to determine whether the variables corresponding to the questions of the first two sections of the questionnaire were statistically related to the socio-demographic characteristics of the respondents. A chi-square test is considered unreliable if more than $20 \%$ of the expected values are less than five. In the cases where tests were not reliable, variables were grouped in order to overcome this shortcoming. A 2-sided p-value less than 0.05 is considered to be significant. 


\section{Results and discussion}

\section{Analysis of the sociodemographic characteristics of the sample}

Table 2 shows the frequency and percentages of the socio-demographic profiles of the respondents. As it is clear from this table, $48.8 \%$ of the respondents are male and 51.2\% female. Among the 500 participants, 329 of them (65.8\%) are aged 25-54 years. The average age of respondents is 43 years, with a standard deviation of 13.8 years. Almost 6\% of the respondents have a primary/secondary school education. Respondents with high school education and university education account for $30.6 \%$ and $44.6 \%$ respectively. With regard to marital status, $57 \%$ of the respondents are married. The majority of respondents, approximately $50 \%$, are private employees and civil servants (25.6\% and 23.8\% respectively), $12 \%$ are self-employed and $12.2 \%$ are retired. The number of student respondents was 6\%. Some $3.6 \%$ were homeworkers and $6 \%$ had temporary employment. Almost 11\% were unemployed. The average income of respondents was between $€ 10,000-20,000$ (US\$11,796- US\$23,591), while one third earned less than $€ 10,000$ (US\$11,796).

\begin{tabular}{|c|c|c|c|}
\hline Variables & & Frequency $(n=500)$ & Percentage (\%) \\
\hline \multirow{2}{*}{ Gender } & Female & 256 & 51.2 \\
\hline & Male & 244 & 48.8 \\
\hline \multirow[t]{5}{*}{ Age Level } & $18-24$ & 47 & 9.4 \\
\hline & $25-44$ & 229 & 45.8 \\
\hline & $45-54$ & 100 & 20 \\
\hline & $55-64$ & 67 & 13.4 \\
\hline & $65-74$ & 57 & 11.4 \\
\hline \multirow[t]{5}{*}{ Education } & $\begin{array}{l}\text { Primary/secondary } \\
\text { school }\end{array}$ & 31 & 6.2 \\
\hline & High school & 153 & 30.6 \\
\hline & Higher education & 223 & 44.6 \\
\hline & Master Diploma & 78 & 15.6 \\
\hline & $\mathrm{PhD}$ & 15 & 3 \\
\hline \multirow[t]{2}{*}{ Marital status } & Married & 282 & 56.4 \\
\hline & Not married & 218 & 43.6 \\
\hline \multirow[t]{8}{*}{ Occupation } & Student & 30 & 6 \\
\hline & Private employee & 128 & 25.6 \\
\hline & Civil servant & 119 & 23.8 \\
\hline & Self-employed & 60 & 12 \\
\hline & Part -time job & 30 & 6 \\
\hline & Homeworker & 18 & 3.6 \\
\hline & Unemployed & 54 & 10.8 \\
\hline & Retired & 61 & 12.2 \\
\hline \multirow[t]{7}{*}{ Family income, Euros } & $0-5,000$ & 77 & 15.4 \\
\hline & $5,001-10,000$ & 69 & 13.8 \\
\hline & $10,001-20,000$ & 158 & 31.6 \\
\hline & $20,001-30,000$ & 111 & 22.2 \\
\hline & $30,001-40,000$ & 54 & 10.8 \\
\hline & $40,001-50,000$ & 21 & 4.2 \\
\hline & $>50,000$ & 10 & 2 \\
\hline
\end{tabular}

Table 2: Socio-demographic profile of the respondents.

\section{Section A: Environmental concern}

The first question (Q1) investigated the respondents' concern about the environmental problems. The majority $\left(74 \%=\right.$ sum of the $4^{\text {th }}$ and $5^{\text {th }}$ scales) declared their strong interest in environmental problems and only $3 \%$ (sum of the first two scales) seems to be indifferent to this issue (Table 3-Appendix). The remaining $23 \%$ come from the middle responses on the five point Likert scale. No association between gender, age, education 
level, income or occupation is evident from a chi-squared test of independence. These responses from Athens are in line with other European surveys of environmental attitudes and concern. In the recent Eurobarometer survey EB 468 (Special Eurobarometer 468, 2017), on Attitudes of European citizens towards the environment, some $94 \%$ of EU respondents and $98 \%$ of Greeks declared environmental protection was important (when asked: How important is protecting the environment to you personally?).

Furthermore, when asked about the impact of environmental problems on their daily life (Q2) and the life of future generations (Q3), the vast majority said impacts were major (85.2\%) and also for future generations (95.8\%) (Table 3-Appendix). In a chi-square test the responses to question Q2 are statistically related to gender $\left(\chi^{2}=14.071\right.$, $\mathrm{p}$-value $\left.<0.0005\right)$ and age of the respondents $\left(\chi^{2}=11.273\right.$, $\mathrm{p}$-value $\left.=0.024<0.05\right)$ (Table 4-Appendix). Women responded that they were more affected (91\%) then men (79.1\%) in daily life (Q2); this belief increases with the respondents' age (55-64: 94\%, 18-24: 78.7\%). The impact of environmental problems to the life of future generations (Q3) was related to their gender $\left(\chi^{2}=6.582\right.$, $p$-value $\left.=0.01<0.05\right)$, similar to the previous question (Table 4-Appendix). The Eurobarometer survey EB 468 (Special Eurobarometer 468, 2017) found 81\% of Europeans and $97 \%$ of the Greek respondents agreed that environmental issues have a direct effect on their daily life. Women and the middle/older age groups, both in our survey and in European research, are more sensitive to environmental issues and their influence on their daily lives, than men and younger groups.

With regard to the main source of information about environmental issues (Q4.1, Q4.2, Q4.3, Q4.4, Q4.5), $73.7 \%$ of the participants admit that the internet is the principal source, followed by magazines/newspapers (41.3\%), television/radio (39.1\%), and family information (25\%). The educational system comes last (15\%) (Table 3-Appendix). The Hellenic Statistic Authority found similar results on information sources in Greece (Hellenic Statistical Authority 2017). According to that survey 71\% of households had internet access at home, 68.4\% used a personal computer (PC) (at home, at work, in education, etc.) in the $1^{\text {st }}$ quarter of 2017 and $69.9 \%$ accessed the internet in the $1^{\text {st }}$ quarter of 2017 . Also, more than 7 out of 10 people used a mobile device away from home in the same period. This is unsurprising, with the Internet being the source of information for billions of people. A chi-squared test for independence indicates some association between considering the educational system as a main source of information, and age $\left(\chi^{2}=22.633\right.$, p-value $<0.0005)$, educational level $\left(\chi^{2}=16.530\right.$, p-value $\left.=0.02<0.05\right)$ and occupation $\left(\chi^{2}=18.397\right.$, pvalue $=0.018<0.05)$ (Table 4-Appendix). Younger people, those with higher education, students and also the unemployed (the vast majority being young) are more likely to obtain their information from the internet and in education. There is also an association between considering magazines/newspapers as the main source of information and age $\left(\chi^{2}=31.114\right.$, p-value $\left.<0.0005\right)$, marital status $\left(\chi^{2}=9.251\right.$, p-value $\left.=0.002<0.05\right)$, income $\left(\chi^{2}=14.685\right.$, $\mathrm{p}$-value $\left.=0.023<0.05\right)$ and occupation $\left(\chi^{2}=24.603\right.$, $\mathrm{p}$-value $\left.=0.002<0.05\right)$. Older respondents, the retired and homeworkers are more likely to rely on TV/radio and magazines/newspapers.

Despite a strong environmental concern, almost $77 \%$ of the respondents said that they are not willing to bear a greater financial burden in order increase the capital allocated to environmental protection actions (Q5) (Table 3-Appendix). No association between the answers for this question and gender, age, education level, income or occupation was found by a chi-squared test of independence. The low 'willingness to pay' reflects the economic tightening on Greek citizens as a result of the economic crisis, and the lack of trust of the state for its revenue management for environmental protection. Distrust of the state was intense in the period of the economic crisis: and Greece is still in the grip of financial austerity measures. Household incomes are generally low (Siamanta 2017). This is also present across Europe. According to EB 86 (Standard Eurobarometer 86, 2016), on Public Opinion in the European Union, unemployment emerges as the most important problem at national level, in Greece 55\% noting it, and 33\% identified its poor economic position. The environment was in last place in this survey (climate changes and energy issues: 1\%). Eurobarometer survey EB 468 (Special Eurobarometer 468, 2017) showed a lack of trust in the state, and the majority of Europeans believe that the EU and national governments are not doing enough to protect the environment (67\% of respondents believe that their national government is not doing enough to protect the environment, but $88 \%$ in Greece). It seems that people who have difficulties paying their bills are more likely to feel that institutions are not doing enough to protect the environment, compared with those who never, or almost never, have financial difficulties.

However, almost $75 \%$ of the respondents positively about whether they are willing to pay higher prices for purchasing products that respect/protect the environment (Q6) (Table 3-Appendix). This seems like a 
reversal of the previous question response; but the question is personal to the respondent and any benefit comes directly to her or him. It seems many consumers are ready to pay higher prices for products that comply with environmental standards: preserving the environment has caused consumers to rethink their choice of products (Newton et al. 2015). A similar trend is also recorded in European survey EB 416 among European citizens (Special Eurobarometer 416, 2014) where 75\% (72\% of Greeks) agree they would buy environmentally friendly products even if they cost a little more. In the same European survey, environmental purchasing was one of the three main environmental priorities (Special Eurobarometer 416, 2014). Some 22\% of European citizens and $34 \%$ of Greeks said they would do this. No association between our survey question and gender, age, education level, income or occupation was found.

Our respondents were asked if environmental policy (central or regional) implemented in Greece is effective for protect the environment (Q7). The response was strongly negative (83\%) and only $1 \%$ positive, with $16 \%$ giving neutral answers (Table 3-Appendix). No association was found between gender, age, education level, income or occupation. In European survey EB 416 (Special Eurobarometer 416, 2014), 70\% of Europeans (91\% of Greeks) gave the same response, and 88\% of Europeans (96\% of Greeks) expressed their distrust to the credibility of the environmental information provided by the state. This suggests a lack of trust in the state regarding the implementation of environmental policy, particularly in Greece but also across Europe.

A little more than the two-thirds of our respondents (69.2\%) indicate that economic growth can be achieved while protecting the environment (Q8) (Table 3-Appendix). No association between gender, age, education level, income or occupation is indicated by the result of a chi-squared test of independence carried out on the respondents' answers. The findings are also comparable with those obtained from Eurobarometer survey EB 416 (Special Eurobarometer 416, 2014), where 74\% of Europeans and 88\% of Greeks believed that environmental protection can boost economic growth in the European Union.

\section{Section B: Aware of the concept of ecological debt and its dimensions}

Almost a quarter of respondents (24\%) claim that they are aware of the concept of ecological debt, while $50 \%$ of the respondents said they were not, and $26 \%$ placed in the middle of the five point Likert scale (Q9) (Table 3-Appendix). Significantly, some respondents revealed at the end of the interview that they had misunderstood the meaning of the concept. On the basis of a chi-square test, the answers to the question are statistically related to education status $\left(\chi^{2}=10.791\right.$, $p$-value $\left.=0.029<0.05\right)$ and income $\left(\chi^{2}=18.664\right.$, $p$-value $=$ $0.005<0.05)$ (Table 4-Appendix). Respondents with the highest annual income $(>€ 50,000$, US\$58,980) seem more aware of the concept (70\%) than those of the lowest income (€0-5,000, US\$0-5,898, 27.3\%). There is an increase in knowledge with educational level, with master diploma holders being more aware than those that finished education at primary/secondary school (33.3\% against 16.1\%).

The next question aims to investigate the possible differences to the implementation of environmental policy between developing and developed countries (Q10). Almost 54\% of the respondents agree that the developing countries implement less strict environmental policy than the developed ones (Table 3-Appendix). $24.7 \%$ seems wary of this aspect and almost $22 \%$ expresses their disagreement. The majority is therefore convinced that economically weaker countries implement a less strict environmental policy. Chi-square test results reveals a statistically significant difference with gender $\left(\chi^{2}=6.300\right.$, $\mathrm{p}$-value $\left.=0.012<0.05\right)$, education level $\left(\chi^{2}=12.135\right.$, p-value $\left.=0.016<0.05\right)$ and respondents income $\left(\chi^{2}=16.452\right.$, p-value $\left.=0.011<0.05\right)($ Table 4-Appendix). Men believe more than women that developing countries implement less strict environmental policy (almost $60 \%$, against 52\% of women respondents), as well as the respondents with higher education and higher income.

Question 11 assessed the possible reasons for developed countries relocating their industrial activities to developing ones. The vast majority (94.6\%) identified cheaper labor in developing countries, followed by the exploitation of natural resources (90.2\%), less strict labor legislation (89.4\%), lesser waste management standards and environmental legislation ((86.8\% and 83\%) (Table 3-Appendix). There is little differentiation in these responses. Respondents also noted the environmental exploitation of economically weaker countries by the richest ones. In our study, a statistically significant difference is found between education level of respondents and the cause of cheaper labor they identified $\left(\chi^{2}=14.749\right.$, $\mathrm{p}$-value $\left.=0.005<0.05\right)$. Masters and PhD 
holders declared a stronger belief (100\%) than high school graduates (89.5\%) (Table 4-Appendix). There is significant gender difference $\left(\chi^{2}=7.358\right.$, $p$-value $\left.=0.007<0.05\right)$, as women believed more strongly in the important role of cheaper labor. Age is an independent factor in predicting the respondents' answers on less strict environmental legislation $\left(\chi^{2}=20.880\right.$, $p$-value $\left.<0.0005\right)$; this belief increased with age $(18-24$ : 63.8\%, 6574: 86\%).

Linking ecological debt and external financial debt in Greece, Q12 asked if the environmental exploitation of a developing country by developed ones should lead to the reduction of the former's financial debt, given the sacrifices made to supply developed countries with goods and raw materials. Some 65\% agreed, with only $16.1 \%$ disagreeing and the remaining 19.3\% ambivalent (Table 3-Appendix). No association between gender, age, education level, income or occupation existed. Those in agreement recognized environmental exploitation of economic weaker countries by the richer ones and expressed their concern, wanting justice and moral and financial compensation. Linking external debt to ecological debt is an action point for environmental movements, particularly in Greece with its large financial debt to other nations and organizations, most of them considerably richer.

When the respondents were asked if they believe Greece should adopt less strict environmental legislation (Q13.1) or less strict labor laws (Q13.2) to encourage foreign investments and cope with its financial debt, the majority of the participants disagreed (76.2\% and 69.8\% respectively) (Table 3-Appendix). In contrast, only $12 \%$ and 16\% concurred (Q13.1 and Q13.2). There was a negative connection between educational level and accepting less strict environmental legislation $\left(\chi^{2}=23.319\right.$, p-value $\left.<0.0005\right)$, with stronger supporters having lower education levels (29\% with primary/secondary education said yes, against 3.8\% master or degree holders) (Table 4-Appendix). This is understandable given their economic plight and high unemployment (more than $21 \%$ unemployed in 2017, against $9.6 \%$ in 2009, just before the beginning of the economic crisis) with thousands of potential workers are out of a job (Hellenic Statistical Authority 2017). The crisis has contributed to the devaluation of environmental issues, since everyone's interest has been focused on meeting vital and basic needs that can no longer taken for granted. In other nations economic recession and the rise of anti-scientific beliefs has diverted attention away from environmental issues among citizens and political parties (Pammett 2015) and it seems that the 2007-8 global recession may have further eroded public support for environmental action (Dalton 2015). A recent Eurobarometer survey (Special Eurobarometer 468, 2017), found unemployment was the most important issue facing Greece (54\%), followed by its economic situation (46\%), with the state of the environment in last place.

When asked whether respondents believed that developed countries with industrial activity in Greece owe an ecological debt to the country (Q14), 78.3\% of the respondents agreed, $14.5 \%$ expressed reservations and only 7.2\% responded negatively (Table 3-Appendix). Chi-square tests reveal a statistically significant difference between respondents' answers and gender $\left(\chi^{2}=21.471\right.$, p-value $\left.<0.0005\right)$, as women believed more strongly in the existence of such an ecological debt than men (86.7\% against 69.5\%) (Table 4-Appendix).

Furthermore when the respondents were asked if they believe that Greece must pay off its financial debt (Q15), the responses were clearly against its repayment; almost $45 \%$ of the participants disagreed, 32\% were not sure and only $23 \%$ agreed (Table 3-Appendix). These attitudes are directly related to citizens' dissatisfaction with the economic measures imposed (increased unemployment, wage reduction, tax increases, institutional changes, etc.), especially among the lower economic classes. We found an association between the respondents' answers and gender, age and occupation. Women (80.6\%), middle aged people aged 45-54 (88.5\%), private employees (82.9\%), civil servants (82.8\%) and the unemployed (77.4\%) emerged as the greater supporters of the non-repayment of financial debt, while men (72.7\%), elderly respondents aged 65-74 (40.4\%), retired people (60.7\%) and students (63\%) were less opposed to repayment (Table 4-Appendix).

\section{The relationship between public knowledge and perception of ecological debt with political ecology}

Political ecology highlights the environmental pressures that the planet receives from economic growth. The key tenets of political ecology have emerged out of concerns about ecological devastation and deterioration of the quality of human life because of human activities (Mansfield 2009). Political ecology recognizes that environmental issues are not simply biophysical problems to be solved by markets or better 
technology, but it understands environmental problems as simultaneously social and political-economic problems (Osborne 2017). It seeks a more radical global perspective through the changing attitudes, perceptions and values of citizens in order to induce a conscious reassignment towards an alternative model of social and economic organization. Ecological debt is an environmental issue that gels with many aspects of political ecology: ecological and social injustice, over- and unequal exploitation of natural resources and labor, production and consumption patterns and, the most important, a direct link is made between ecological debt and external financial debt, particularly of the poorest countries. The latter point is particularly relevant for a country such as Greece, because of its long engagement with external financial debt, that led to a series of austerity measures and deep fiscal changes. The application of the Greek economic adjustment program had a great effect on the Greek economy. The majority of macroeconomic aggregates (mainly GDP and unemployment) worsened; Gross Domestic Product (GDP) decreased constantly since 2009 and as mentioned above, unemployment increased from 9.9\% in 2005 to 21\% in 2017 (Hellenic Statistical Authority 2018). The Greek people face falling wages, pension cuts and tax rises. Essential services such as healthcare have been cut back; also worker's compensation and social benefits. The management of financial debt is a serious issue because severely indebted countries often engage in economic activity that is harmful to natural environments in the hope of gaining adequate export revenue, to repay external debts (Kox 1997; Muradian and MartinezAlier 2001). Likewise, many less-developed countries, in an effort to attract foreign investment and transnational enterprises, have relaxed labor and environmental laws and reduced taxes (Jorgenson 2016).

There is a deep engagement of political ecology with social movements and organizations that are dealing with the conservation of natural resources, the fight against poverty, and the struggle for environmental justice. These social movements and organizations can be the place of elaboration of political ecology's ideas outside the university. Our findings highlight some alternative proposals for these social movements and organizations for the design of 'wake-up' policies by highlighting the broader consequences of consumption patterns and the nature of debt. A starting point is to share the survey with official bodies and policymakers. The discourses of ecological debt have a pedagogical function, helping citizens to recognize the exploitation of the South by the North and to support financial debt relief. Ecological debt does not work only at the scale of nations states or individual actions: there are other important actors and relationships (eg. corporations vs. residents, high-income vs. low-income households...) (Warlenius 2016). By raising awareness of the concept of ecological debt, we hope to encourage more responsible, less environmentally damaging consumption and to contribute to an equitable and sustainable future.

\section{Conclusions}

The survey presented in this article explored Greek public opinion on ecological debt, and perceptions and knowledge of the concept. It was a preliminary effort to gauge public opinion in Athens. Similar surveys are required in the future. Surveys provide valuable feedback for social movements and contribute to raising citizen awareness.

We found the vast majority of the respondents express high levels of concern about environmental problems, and face them as an issue that affects their daily life and the life of future generations. There is a general lack of trust of the state for its management of environmental protection and for the implementation of environmental policy. There is a greater willingness at individual level to contribute to actions like purchasing products that respect and/or protect the environment.

The concept of ecological debt is not widely used or understood; three-quarters of the respondents were unaware of the concept. Almost six out of ten argued that developing countries implement a less strict set of environmental policies than developed ones, and they acknowledged the environmental exploitation of the economically weakest countries by the richest ones. A majority recognized exploitation of natural resources, a cheaper labor force, less strict labor policies and environmental legislation as reasons for the development of industrial activity in these countries. Two-thirds of the respondents strongly endorse the link between ecological debt and the financial debt of Greece, and strongly supported financial debt relief. Two-thirds do not support the adoption of less strict environmental and working legislation in Greece to encourage foreign investments 
and to cope with external financial debt. Finally, almost one in two are against the repayment of Greece's large financial debt, despite the socio-political pressures that citizens face for urgent repayment.

The results show that residents of Athens are environmentally aware and acknowledge the components of ecological debt. The financial difficulty they are experiencing, and the acceptance of part of the population to sacrifice environmental standards and work achievements in order to find a job, were a feature of the survey responses. The majority, however, oppose the reimbursement of Greece's foreign debt.

The findings also suggest that political ecology and associated concepts like ecological debt could have a role in spreading new and useful elements and ideas that can feed activism and the work of social movements, fostering an understanding of the kinds of injustices that occur on a global scale. This could include building solidarity between communities and raising awareness of how everyday lives are connected through various social and economic processes to the lives of people all over the world. Awareness of the concept of ecological debt is part of responsible and less environmentally damaging consumption, and creating an equitable and sustainable future.

\section{References}

Acción Ecológica. 1999. No more plunder, they owe us the ecological debt! Bulletin of Acción Ecológica. Quito, Ecuador: Acción Ecológica:

Azar, C. and J. Holmberg. 1995. Defining the generational environmental debt. Ecological Economics 14: 719.

Bravo, E. and I. Yánez (eds.). 2003. No more looting and destruction! We the peoples of the south are ecological creditors. Quito Ecuador: Alliance SPEDCA.

Brundtland, G. 1987. Our common future: the world commission on environment and development. Oxford: Oxford University Press.

Dalton, R.J. 2015. Environmental concerns during a time of duress: an introduction. Environmental Politics 24(4): 523-529.

Debt Treaty. 1992. Non-Governmental Organization (NGO) alternative treaties at the 1992 Global Forum: alternative economic issues. Rio de Janeiro, Brazil. http://www.earthsummit2002.org/toolkits/women/ngo-doku/ngo-conf/ngoearth2-2.html

Donoso, A. 2003. We are not debtors, we are creditors. In Bravo, E. and I. Yánez (eds.) No more looting and destruction! We the peoples of the South are ecological creditors. Quito Ecuador: Alliance SPEDCA.

Eyerman, R. and A. Jamison. 1991. Social movements: a cognitive approach. Cambridge: Polity Press.

Fink, A. 2006. How to conduct surveys: a step-by-step guide. Third ed. Thousand Oaks, CA: Sage

Goeminne, G. and E. Paredis. 2008. The concept of ecological debt: an environmental justice approach to sustainability, calling for radical transitions in industrialized countries. Paper presented at the $7^{\text {th }}$ Global Conference on Environmental Justice and Global Citizenship, July 2008. Oxford, UK.

Goeminne, G. and E. Paredis. 2010. The concept of ecological debt: some steps towards an enriched sustainability paradigm. Environment, Development and Sustainability 12: 691-712.

Hellenic Statistical Authority. 2017. 2011 Population-Housing Census. [accessed November 2017]. http://www.statistics.gr/en/2011-census-pop-hous

Hellenic Statistical Authority. 2017. Labor force/time series, employment status and unemployment rate (January 2004 - November 2017. [accessed November 2017]. http://www.statistics.gr/el/statistics//publication/SJO02

Hellenic Statistical Authority. 2017. Use of information and communication technologies by households and individuals (ICT)/2017. [accessed November 2017]. http://www.statistics.gr/en/statistics//publication/SFA20

Hellenic Statistical Authority. 2018. Labor force survey [accessed August 2018] http://www.statistics.gr/en/infographic-labour-force?inheritRedirect=true 
IPCC, 1992. Climate change 1992: the supplementary report to the IPCC scientific assessment. J.T. Houghton, B.A. Callander and S.K. Varney (eds.). Cambridge: Cambridge University Press.

Jorgenson, K.A. 2016. The sociology of ecologically unequal exchange, foreign investment dependence and environmental load displacement: summary of the literature and implications for sustainability. Journal of Political Ecology 32: 334-349.

Kothari, C.R. 1990. Research methodology, methods and techniques. Second revised ed. India: New Age International Publishers.

Manzano, J.J., A. Cardesa-Salzmann, A. Pigrau and S. Borràs. 2016. Measuring environmental injustice: how ecological debt defines a radical change in the international legal system. Journal of Political Ecology 23: 381-393.

Martínez Alier, J. 2002. The environmentalism of the poor: a study of ecological conflicts and valuation. Cheltenham, UK: Edward Elgar.

Martinez-Alier, J., I. Anguelovski, P. Bond, D. Del Bene, F. Demaria, J.-F. Gerber, L. Greyl, H. Healy, V. Marín-Burgos, G. Ojo, M.F. Porto, L. Rijnhout, B. Rodríguez-Labajos, J. Spangenberg, L. Temper, R. Warlenius and I. Yánez. 2014. Between activism and science: grassroots concepts for sustainability coined by environmental justice organizations. Journal of Political Ecology 21: 19-60.

Mayer, A. and W. Haas. 2016. Cumulative material flows provide indicators to quantify the ecological debt. Journal of Political Ecology 23: 351-363.

McCall, C.H. Jr. 1982. Sampling and statistics: handbook for research. Ames: Iowa State Press.

Muradian, R. and J. Martinez-Alier. 2001. Trade and the environment: from a "southern" perspective. Ecological Economics 36: 281-297.

Nardi, P.M. 2006. Doing survey research: a guide to quantitative methods. Second ed. Boston: Pearson Education.

Newton, J., Y. Tsarenko, C. Ferraro and S. Sands. 2015. Environmental concern and environmental purchase intentions: the mediating role of learning strategy. Journal of Business Research 68(9): 1974-1981.

Osborne, T. 2017. Public political ecology: a community of praxis for earth stewardship. Journal of Political Ecology 24: 844-860.

Pammett, J. 2015. Faith that science will solve environmental problems: does it hurt, or help? Environmental Politics 24(4): 553-574.

Paredis, E., G. Goeminne, W. Vanhove, F. Maes and J. Lambrecht. 2008. The concept of ecological debt: its meaning and applicability in international policy. Ghent: Academia Press.

Rice, J. 2009. North South relations and the ecological debt: asserting a counter-hegemonic discourse. Critical Sociology 35: 225-252.

Siamanta, Z.C. 2017. Building a green economy of low carbon: the Greek post-crisis experience of photovoltaics and financial 'green grabbing'. Journal of Political Ecology 24: 258-276.

Smith, K.R. 1996. The natural debt: north and south. In Giambellucu, T.W. and A. Henderson-Sellers (eds.). Climate change: developing southern hemisphere perspectives. Chichester: Wiley.

Special Eurobarometer 365 / Wave EB75.2 (Fieldwork April-May 2011), Publication August 2011. Attitudes of European citizens towards the environment.

Special Eurobarometer 416 / Wave EB81.3 (Fieldwork: April-May 2014), Publication September 2014. Attitudes of European citizens towards the environment.

Standard Eurobarometer 86 /Wave EB86.2 (Fieldwork November 2016), Publication December 2016. Public opinion in the European Union.

Special Eurobarometer 468 / Wave EB88.1 (Fieldwork September-October 2017), Publication November 2017. Attitudes of European citizens towards the environment.

Special Eurobarometer 468/ Wave EB88.1 (Fieldwork September-October 2017), Publication November 2017. Attitudes of European citizens towards the environment.

SPSS, 2006. SPSS for Windows, Rel.14.0 statistical package for social sciences. Chicago: SPSS Inc. 
Srinivasan, U.T., S.P. Carey, E. Hallsteind, P.A.T. Higgins, A.C. Kerr, L.E. Koteen, A.B. Smith, R. Watson, J. Harte and R.B. Norgaard. 2008. The debt of nations and the distribution of ecological impacts from human activities. Proceedings of the National Academy of Sciences of the USA 105: 1773-1786.

Torras, M. 2003. An ecological footprint approach to external debt relief. World Development 31(12): 21612171.

Warlenius, R. 2016. Linking ecological debt and ecologically unequal exchange: stocks, flows, and unequal sink appropriation. Journal of Political Ecology 23: 365-380.

Warlenius, R., G. Pierce and V. Ramasar. 2015. Reversing the arrow of arrears: the concept of 'ecological debt' and its value for environmental justice. Global Environmental Change 30: 21-30. 


\section{Appendix}

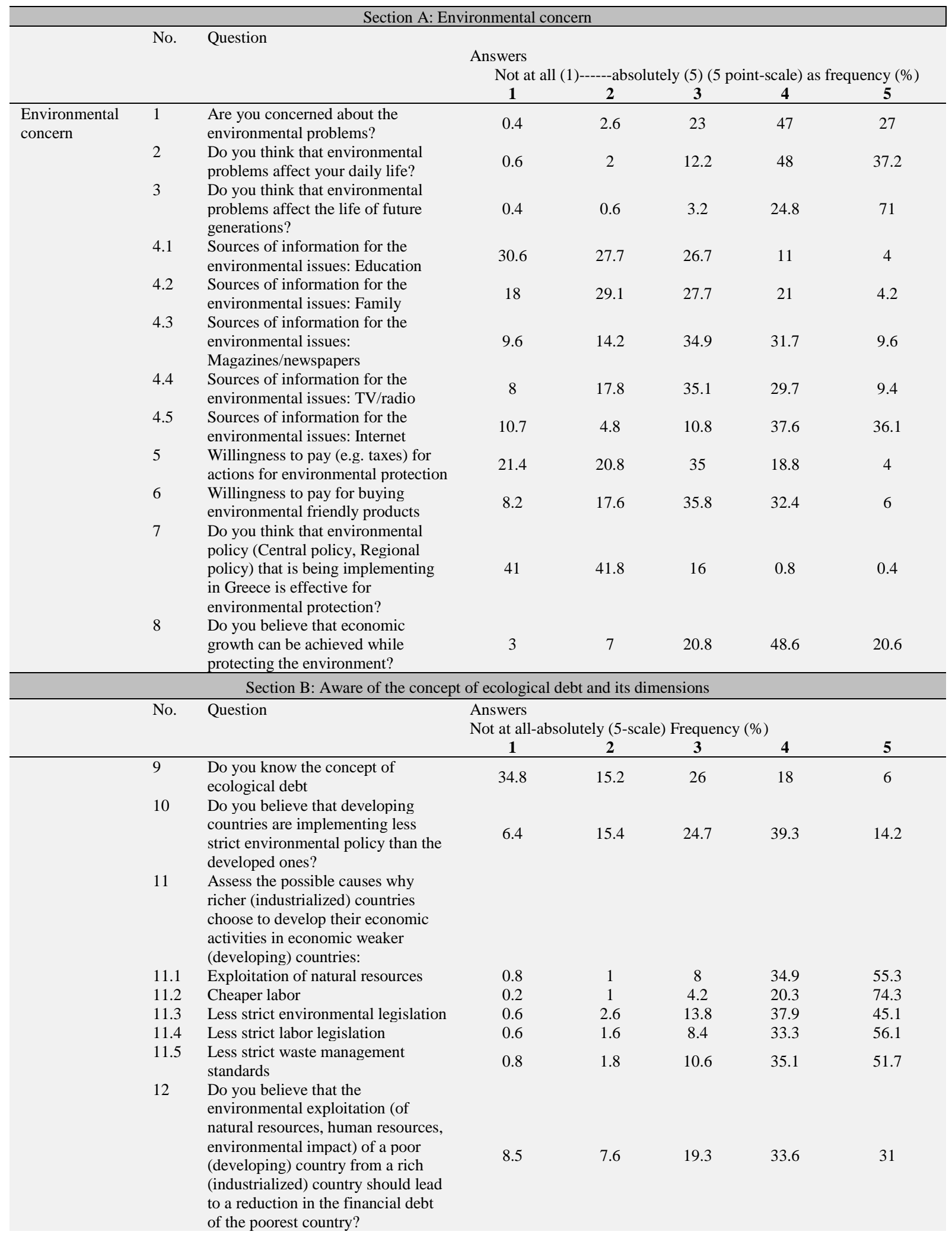




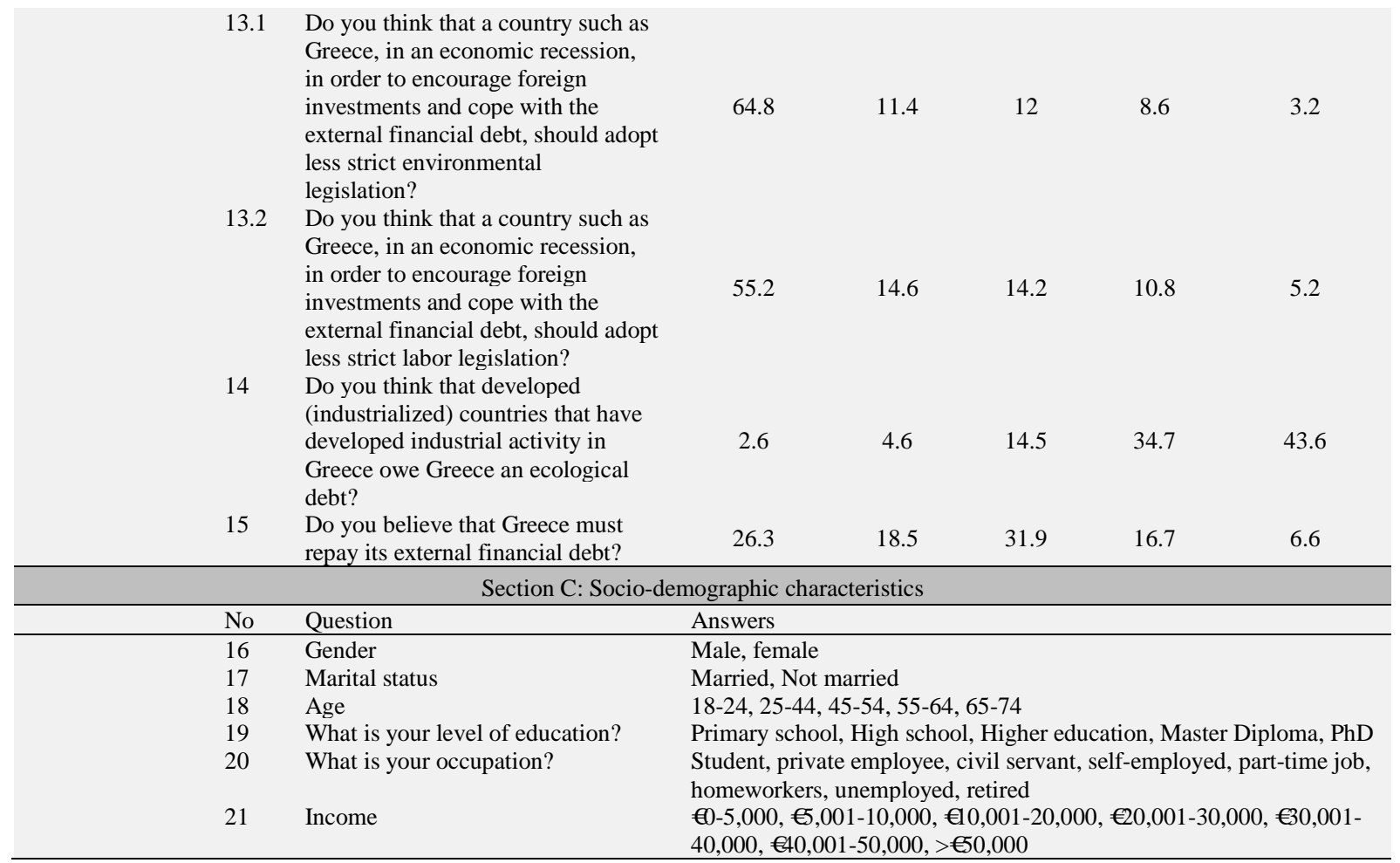

Table 3. The questionnaire used.

\begin{tabular}{|c|c|c|c|c|c|c|}
\hline Question & & & $\begin{array}{l}\text { Percentage } \\
\text { (\%) } \\
\text { Low }\end{array}$ & $\begin{array}{l}\text { Percentage } \\
\text { (\%) } \\
\text { High }\end{array}$ & $\begin{array}{l}\text { Pearso } \\
\text { n Chi- } \\
\text { square }\end{array}$ & $\mathrm{p}$-value \\
\hline \multirow[t]{6}{*}{ Q2 } & Gender & Male & 79.1 & 20.9 & 14.071 & $<0.0005$ \\
\hline & & Female & 91 & 9 & & \\
\hline & Age & $18-24$ & 78.7 & 21.3 & 11.273 & 0.024 \\
\hline & & $25-44$ & 81.2 & 18.8 & & \\
\hline & & $45-54$ & 91 & 9 & & \\
\hline & & $55-64$ & 94 & 6 & & \\
\hline \multirow[t]{2}{*}{ Q3 } & Gender & Male & 93.4 & 6.6 & 6.582 & 0.01 \\
\hline & & Female & 98 & 2 & & \\
\hline \multirow[t]{18}{*}{ Q4.1 } & Age & $18-24$ & 36.2 & 63.8 & 22.633 & $<0.0005$ \\
\hline & & $25-44$ & 14 & 86 & & \\
\hline & & $45-54$ & 14.1 & 85.9 & & \\
\hline & & $55-64$ & 14.9 & 85.1 & & \\
\hline & & $65-74$ & 3.5 & 96.5 & & \\
\hline & Education status & $\begin{array}{l}\text { Primary/secondary } \\
\text { school }\end{array}$ & 6.5 & 93.5 & 16.530 & 0.02 \\
\hline & & High school & 9.2 & 90.8 & & \\
\hline & & Higher education & 15.7 & 84.3 & & \\
\hline & & Master Diploma & 28.2 & 71.8 & & \\
\hline & & $\mathrm{PhD}$ & 13.3 & 86.7 & & \\
\hline & Occupation & Student & 17.9 & 82.1 & 18.397 & 0.018 \\
\hline & & Private employee & 14.1 & 85.9 & & \\
\hline & & Civil servant & 14.4 & 85.6 & & \\
\hline & & Self-employed & 11.7 & 88.3 & & \\
\hline & & Part-time job & 10 & 90 & & \\
\hline & & Homeworkers & 11.1 & 88.9 & & \\
\hline & & Unemployed & 33.3 & 66.7 & & \\
\hline & & Retired & 8.2 & 91.8 & & \\
\hline
\end{tabular}




\begin{tabular}{|c|c|c|c|c|c|c|}
\hline \multirow[t]{10}{*}{ Q4.2 } & \multirow[t]{2}{*}{ Marital status } & Married & 31.6 & 68.4 & 13.679 & $<0.0005$ \\
\hline & & Not married & 17.1 & 82.9 & & \\
\hline & \multirow[t]{8}{*}{ Occupation } & Student & 17.9 & 82.1 & 17.571 & 0.025 \\
\hline & & Private employee & 34.4 & 65.6 & & \\
\hline & & Civil servant & 24.6 & 75.4 & & \\
\hline & & Self-employed & 31.7 & 68.3 & & \\
\hline & & Part-time job & 13.3 & 86.7 & & \\
\hline & & Homeworkers & 33.3 & 66.7 & & \\
\hline & & Unemployed & 11.1 & 88.9 & & \\
\hline & & Retired & 21.3 & 78.7 & & \\
\hline \multirow[t]{22}{*}{ Q4.3 } & \multirow[t]{5}{*}{ Age } & $18-24$ & 19.1 & 80.9 & 31.114 & $<0.0005$ \\
\hline & & $25-44$ & 34.1 & 65.9 & & \\
\hline & & $45-54$ & 51.5 & 48.5 & & \\
\hline & & $55-64$ & 47.8 & 52.2 & & \\
\hline & & $65-74$ & 63.2 & 36.8 & & \\
\hline & \multirow[t]{2}{*}{ Marital status } & Married & 47.2 & 52.8 & 9.251 & 0.002 \\
\hline & & Not married & 33.6 & 66.4 & & \\
\hline & \multirow[t]{7}{*}{ Income } & $€ 0-5,000$ & 31.2 & 68.8 & 14.685 & 0.023 \\
\hline & & $€ 5,001-10,000$ & 34.8 & 65.2 & & \\
\hline & & $€ 10,001-20,000$ & 37.6 & 62.4 & & \\
\hline & & $€ 20,001-30,000$ & 48.6 & 51.4 & & \\
\hline & & $€ 30,001-40,000$ & 53.7 & 46.3 & & \\
\hline & & $€ 40,001-50,000$ & 42.9 & 57.1 & & \\
\hline & & $>€ 50,000$ & 70 & 30 & & \\
\hline & \multirow[t]{8}{*}{ Occupation } & Student & 21.4 & 78.6 & 24.603 & 0.002 \\
\hline & & Private employee & 40.6 & 59.4 & & \\
\hline & & Civil servant & 40.7 & 59.3 & & \\
\hline & & Self-employed & 45 & 55 & & \\
\hline & & Part-time job & 43.3 & 56.7 & & \\
\hline & & Homeworkers & 38.9 & 61.1 & & \\
\hline & & Unemployed & 25.9 & 74.1 & & \\
\hline & & Retired & 63.9 & 36.1 & & \\
\hline \multirow[t]{13}{*}{ Q4.4 } & \multirow[t]{5}{*}{ Age } & $18-24$ & 12.8 & 87.2 & 33.083 & $<0.0005$ \\
\hline & & $25-44$ & 33.6 & 66.4 & & \\
\hline & & $45-54$ & 43.4 & 56.6 & & \\
\hline & & $55-64$ & 50.7 & 49.3 & & \\
\hline & & $65-74$ & 61.4 & 38.6 & & \\
\hline & \multirow[t]{8}{*}{ Occupation } & Student & 14.3 & 85.7 & 44.762 & $<0.0005$ \\
\hline & & Private employee & 40.6 & 59.4 & & \\
\hline & & Civil servant & 40.7 & 59.3 & & \\
\hline & & Self-employed & 25 & 75 & & \\
\hline & & Part-time job & 30 & 70 & & \\
\hline & & Homeworkers & 66.7 & 33.3 & & \\
\hline & & Unemployed & 25.9 & 74.1 & & \\
\hline & & Retired & 67.2 & 32.8 & & \\
\hline \multirow[t]{17}{*}{ Q4.5 } & \multirow[t]{5}{*}{ Age } & $18-24$ & 85.1 & 14.9 & 67.507 & 0.0005 \\
\hline & & $25-44$ & 84.3 & 15.7 & & \\
\hline & & $45-54$ & 73.7 & 26.3 & & \\
\hline & & $55-64$ & 64.2 & 35.8 & & \\
\hline & & $65-74$ & 33.3 & 66.7 & & \\
\hline & \multirow[t]{2}{*}{ Marital status } & Married & 65.6 & 34.4 & 22.219 & $<0.0005$ \\
\hline & & Not married & 84.3 & 15.7 & & \\
\hline & \multirow[t]{5}{*}{ Education status } & $\begin{array}{l}\text { Primary/secondary } \\
\text { school }\end{array}$ & 29 & 71 & 53.033 & $<0.0005$ \\
\hline & & High school & 67.1 & 32.9 & & \\
\hline & & Higher education & 77.6 & 22.4 & & \\
\hline & & Master Diploma & 93.6 & 6.4 & & \\
\hline & & $\mathrm{PhD}$ & 73.3 & 26.7 & & \\
\hline & Occupation & Student & 85.7 & 14.3 & 70.761 & $<0.0005$ \\
\hline & & Private employee & 80.5 & 19.5 & & \\
\hline & & Civil servant & 73.7 & 26.3 & & \\
\hline & & Self-employed & 88.3 & 11.7 & & \\
\hline & & Part-time job & 76.7 & 23.3 & & \\
\hline
\end{tabular}




\begin{tabular}{|c|c|c|c|c|c|c|}
\hline & & $\begin{array}{l}\text { Homeworkers } \\
\text { Unemployed } \\
\text { Retired }\end{array}$ & $\begin{array}{l}27.8 \\
87 \\
30\end{array}$ & $\begin{array}{l}72.2 \\
13 \\
70\end{array}$ & & \\
\hline Q9 & Education status & $\begin{array}{l}\text { Primary/secondary } \\
\text { school } \\
\text { High school } \\
\text { Higher education } \\
\text { Master Diploma } \\
\text { PhD } \\
€ 0-5,000 \\
€ 5,001-10,000 \\
€ 10,001-20,000 \\
€ 20,001-30,000 \\
€ 30,001-40,000 \\
€ 40,001-50,000 \\
>€ 50,000\end{array}$ & \begin{tabular}{l|l|}
16.1 & \\
& \\
16.3 & \\
26.9 & \\
33.3 & \\
73.3 & \\
27.3 & \\
23.2 & \\
17.1 & \\
27.9 \\
27.8 \\
14.3 \\
70
\end{tabular} & \begin{tabular}{l|}
83.9 \\
\\
83.7 \\
73.1 \\
66.7 \\
26.7 \\
72.7 \\
76.8 \\
82.9 \\
72.1 \\
72.2 \\
85.7 \\
30
\end{tabular} & 10.791 & 0.029 \\
\hline Q10 & $\begin{array}{l}\text { Gender } \\
\text { Education status }\end{array}$ & $\begin{array}{l}\text { Male } \\
\text { Female } \\
\text { Primary/secondary } \\
\text { school } \\
\text { High school } \\
\text { Higher education } \\
\text { Master Diploma } \\
\text { PhD } \\
€ 0-5,000 \\
€ 5,001-10,000 \\
€ 10,001-20,000 \\
€ 20,001-30,000 \\
€ 30,001-40,000 \\
€ 40,001-50,000 \\
>€ 50,000\end{array}$ & \begin{tabular}{l|l}
59.3 \\
\\
52 \\
38.7 \\
\\
45.1 \\
57.7 \\
64.1 \\
53.3 \\
48.1 \\
42 \\
48.7 \\
60.4 \\
69.8 \\
71.4 \\
50
\end{tabular} & \begin{tabular}{l|l}
40.7 \\
\\
48 \\
61.3 \\
\\
54.9 \\
42.3 \\
35.9 \\
46.7 \\
51.9 \\
58 \\
51.3 \\
39.6 \\
30.2 \\
28.6 \\
50
\end{tabular} & $\begin{array}{l}6.300 \\
12.135\end{array}$ & 0.016 \\
\hline Q11.2 & $\begin{array}{l}\text { Gender } \\
\text { Education status }\end{array}$ & $\begin{array}{l}\text { Male } \\
\text { Female } \\
\text { Primary/secondary } \\
\text { school } \\
\text { High school } \\
\text { Higher education } \\
\text { Master Diploma } \\
\text { PhD }\end{array}$ & $\begin{array}{l}91.8 \\
97.3 \\
100 \\
\\
89.5 \\
95.1 \\
100 \\
100\end{array}$ & $\begin{array}{l}8.2 \\
2.7 \\
0 \\
\\
10.5 \\
4.9 \\
0 \\
0\end{array}$ & $\begin{array}{l}7.358 \\
14.749\end{array}$ & $\begin{array}{l}0.007 \\
0.005\end{array}$ \\
\hline Q11.3 & Age & $\begin{array}{l}18-24 \\
25-44 \\
45-54 \\
55-64 \\
65-74\end{array}$ & $\begin{array}{l}63.8 \\
80.8 \\
92.9 \\
86.6 \\
86\end{array}$ & $\begin{array}{l}36.2 \\
19.2 \\
7.1 \\
13.4 \\
14\end{array}$ & 20.880 & $<0.0005$ \\
\hline Q13.1 & Education status & $\begin{array}{l}\text { Primary/secondary } \\
\text { school } \\
\text { High school } \\
\text { Higher education } \\
\text { Master Diploma } \\
\text { PhD }\end{array}$ & $\begin{array}{l}29 \\
\\
17.6 \\
7.6 \\
3.8 \\
20\end{array}$ & $\begin{array}{l}71 \\
\\
82.4 \\
92.4 \\
96.2 \\
80\end{array}$ & 23.319 & $<0.0005$ \\
\hline Q14 & Gender & $\begin{array}{l}\text { Male } \\
\text { Female }\end{array}$ & $\begin{array}{l}69.5 \\
86.7\end{array}$ & $\begin{array}{l}30.5 \\
13.3\end{array}$ & 21.471 & $<0.0005$ \\
\hline Q15 & $\begin{array}{l}\text { Gender } \\
\text { Age }\end{array}$ & $\begin{array}{l}\text { Male } \\
\text { Female } \\
18-24 \\
25-44 \\
45-54 \\
55-64\end{array}$ & $\begin{array}{l}27.3 \\
19.4 \\
33.3 \\
22.2 \\
11.5 \\
22.4 \\
\end{array}$ & $\begin{array}{l}72.7 \\
80.6 \\
66.7 \\
77.8 \\
88.5 \\
77.6\end{array}$ & $\begin{array}{l}4.308 \\
19.557\end{array}$ & $\begin{array}{l}0.038 \\
0.001\end{array}$ \\
\hline
\end{tabular}




\begin{tabular}{|c|c|c|c|c|c|}
\hline \multirow{9}{*}{ Occupation } & $65-74$ & 40.4 & 59.6 & & \\
\hline & Student & 37 & 63 & 18.637 & 0.017 \\
\hline & Private employee & 17.1 & 82.9 & & \\
\hline & Civil servant & 17.2 & 82.8 & & \\
\hline & Self-employed & 27.1 & 72.9 & & \\
\hline & Part-time job & 17.9 & 82.1 & & \\
\hline & Homeworkers & 29.4 & 70.6 & & \\
\hline & Unemployed & 22.6 & 77.4 & & \\
\hline & Retired & 39.3 & 60.7 & & \\
\hline
\end{tabular}

Table 4. Variation in respondents' answers based on their gender, marital status, age, educational level, occupation and income. 